\title{
Environmental patterns and biomass distribution of gelatinous macrozooplankton. Three study cases in the South-western Atlantic Ocean* ${ }^{\dagger}$
}

\author{
H.W. MIANZAN ${ }^{1,2}$ and R.A. GUERRERO ${ }^{2,3}$ \\ ${ }^{1}$ CONICET, ${ }^{2}$ INIDEP, ${ }^{3}$ UNMdP, P.O.Box 175, 7600 Mar del Plata, ARGENTINA. E-mail: hermes@mdp.edu.ar
}

\begin{abstract}
SUMMARY: Periodic swarms or blooms of gelatinous macrozooplankton have a negative effect on many human activities such as tourism, fisheries, and industry, but for several reasons (sampling procedures, underestimation of their real abundance, etc.), they have often been neglected in the local literature. The "high spatial resolution" exercise of the South-western Atlantic anchovy Engraulis anchoita Recruitment Project (SARP) was therefore also suitable for estimating standing stocks of "jelly" macrozooplankton, attempting to establish particular environmental patterns exerting control on the spatial distribution of these facultative carnivorous predators in coastal frontal environments. These studies were carried out through a sampling programme on board the German R/V "Meteor" in three different systems, convergence and divergent, in the South-western Atlantic Ocean: Region A $\left(42^{\circ} \mathrm{S}\right)$ on the Argentine shelf, characterised by tidal mixing fronts; Region $\mathrm{B}\left(36^{\circ} \mathrm{S}\right)$, the freshwater outflow from Río de la Plata; and Region C $\left(28^{\circ} \mathrm{S}\right)$, under upwelling events in subtropical waters on the Brazilian shelf. In general, a dominance of gelatinous macrozooplankton, compared with the other fraction of macrozooplankton and micronekton was observed. Mean standing stock of the gelatinous zooplankton was always greater than $50 \%$ of organic carbon (org. C) in every section analysed. The lobate ctenophore Mnemiopsis leidyi dominated the zooplankton biomass in Region A, Argentina. It represented $60 \%$ of total org. C and was more abundant at the stratified zone of the front. Ctenophores were also dominant in Region B, Río de la Plata, where the related species Mnemiopsis mccradyi and the cydippid ctenophore Pleurobrachia pileus comprised $81 \%$ of total org. C. Mnemiopsis was most common in areas of vertical thermal and saline stratification, while Pleurobrachia was dominant in the less stratified areas. Gelatinous zooplankton was also the principal component of the macrozooplankton biomass in Region C, Brazil. The hydromedusae Rhacostoma atlantica and Olindias sambaquiensis dominated both the total and gelatinous biomass $68 \%$ and $7 \%$ of total org. C), being always more abundant under lower thermal stratification. It was found that, both in convergent and divergent local systems, gelatinous plankton tended to aggregate in areas where the presence of isolines outcropping to the surface (associated with production processes) was observed. These results are discussed in the context of existing hypotheses regarding ecosystem production and food webs.
\end{abstract}

Key words: Hydromedusae, Ctenophora, biomass distribution, gelatinous organisms, neritic Macroplankton and micronekton, hydrographic structures, South-western Atlantic Ocean.

\section{INTRODUCTION}

It is well known that gelatinous macrozooplankton (this includes members of the phyla Coelenterata, Ctenophora and Tunicata), reach important con-

*Received March 4, 1999. Accepted June 20, 1999.

Contribution $\mathrm{N}^{\circ} 1111$ of the Instituto Nacional de Investigación y

Desarrollo Pesquero (INIDEP) centrations in certain areas of the world. Aggregations and blooms seem to be usual phenomena for "jelly plankton" (Boero, 1991) and their periodic swarms have a noxious effect on many human activities such as tourism, fisheries, and industry (see Mianzan and Cornelius, 1999). Good examples of these kinds of problems include: Pelagia noctiluca stinging swarms in the Mediterranean Sea (Rottini 
Sandrini and Stravisi, 1981; Bernard, 1984; Rottini Sandrini and Avian, 1991); Black Sea losses of millions of dollars of pelagic fisheries due to competition and predation by the ctenophore Mnemiopsis leidyi (Vinogradov et al., 1989; Zaika and Sergeyeva, 1990; GESAMP, 1997; G.R. Harbison, pers. comm. 1993), and clogging on the refrigeration inlet of power plants in the Baltic Sea due to swarms of Aurelia aurita (Möller, 1984).

The above comments also reflect the fact that the gelatinous plankton is well prepared to impact resources of a system under stress conditions, such as anthropogenic processes (overfishing, eutrophication of semi-enclosed areas), natural deviation from normal physical and climatic conditions, etc (Legovic, 1991; Parsons, 1993, 1996; G.R. Harbison, pers. comm. 1993).

The "jelly" plankton is known to generate enormous populations and can even seasonally dominate the zooplankton biomass in bays and enclosed seas (Papathanassiou et al., 1987; Möller, 1978, 1980; Shushkina and Musayeva, 1983). Biomass estimations provide an indirect way to identify production of a population or an ecosystem (Zaika, 1972), even though biomass estimations for "jelly" organism are still lacking for several parts of the world due to several methodological reasons (see Arai, 1988). This gap in knowledge and its consequence makes it hard to define the ecological role of the gelatinous plankton in the processes of energy transfer in the ocean.

Greve and Parsons (1977) and Parsons (1979) suggested two major pathways for the transfer of energy up the food web of the sea. One of these pathways, identified for upwelling (highly productive) ecosystems tends toward food production favouring carnivorous fishes. The other one, for convergent (less productive) ecosystems, tends toward food chains favouring carnivorous jellyfishes (medusae and ctenophores).

Several objections to this hypothesis have been published, based on its generalization (see Arai, 1988; Smayda, 1993) and recently Mills (1995) modified the endpoint of the hypothesis by stating that jellyfishes are present nearly to the same extent in convergent ecosystems as in upwelling ones.

Both hypotheses (Greve and Parsons, 1977; Mills, 1995) refer to ecological rules on a global scale. At meso-scale $(100-1000 \mathrm{~km})$, very little is known about jellyfish distribution, since it is mainly affected by physical processes (bottom-up control) such as local upwelling (divergence), river plume fronts, tidal fronts (convergence) (see Arai,
1992). These types of coastal systems are present in the south-western Atlantic Ocean (Bakum and Parrish, 1991).

The "high spatial resolution" exercise of the Southwest Atlantic anchovy Engraulis anchoita Recruitment Project (SARP) was therefore suitable for also estimating standing stocks of jelly plankton and provided the first possibility to test the above mentioned hypotheses. The studies were carried out in three different regions (Fig. 1) in the South-western Atlantic Ocean (Alheit et al., 1991) and comprised:

a- An area in the Argentine shelf, Region A $\left(42^{\circ} \mathrm{S}\right)$, characterized by tidal mixing fronts off Península Valdés (Carreto et. al., 1986a; Glorioso, 1987).

b- An area under the influence of the Río de la Plata freshwater outflow, in the Argentine-Uruguay shelf, Region B $\left(36^{\circ} \mathrm{S}\right)$ (Carreto et al., 1986b; Elgue et al., 1986; Guerrero et al., 1997a,b), and

c- An area characterized by upwelling events in subtropical waters on the Brazilian shelf off Cape Santa Marta Grande, Region C (28ㅇ) (Emilson, 1961; Matsuura, 1986).

The main purpose of this paper is to analyse the biomass of gelatinous, facultative carnivorous predators and the main hydrographic features associated with the study areas, in order to establish environmental patterns exerting control on the spatial distribution of jelly plankton.

\section{OCEANOGRAPHIC FEATURES AND PRODUCTIVITY OF THE STUDY AREAS}

Longhurst et al. (1995) described the Coastal Domain of the South-western Atlantic as one of the most productive regions of the World Ocean. However, within this large ecosystem, productivity is not a homogeneous feature, but is increased locally by several physical processes. The three main scenarios selected are:

Region A: The Patagonian Continental Shelf has high levels of dissipation of tidal energy (Simpson and Bowers, 1981; Glorioso, 1987). The mixing induced by tidal currents contributes to $8.5 \%$ of total tidal energy dissipation of the world ocean (Miller, 1966). The tidal front off Península Valdés is a thermal front, observed in spring and summer, that defines the boundary between stratified (offshore) waters and a coastal, vertically mixed body of water. The stratification of shelf waters is induced by surface warming during spring and summer periods, 


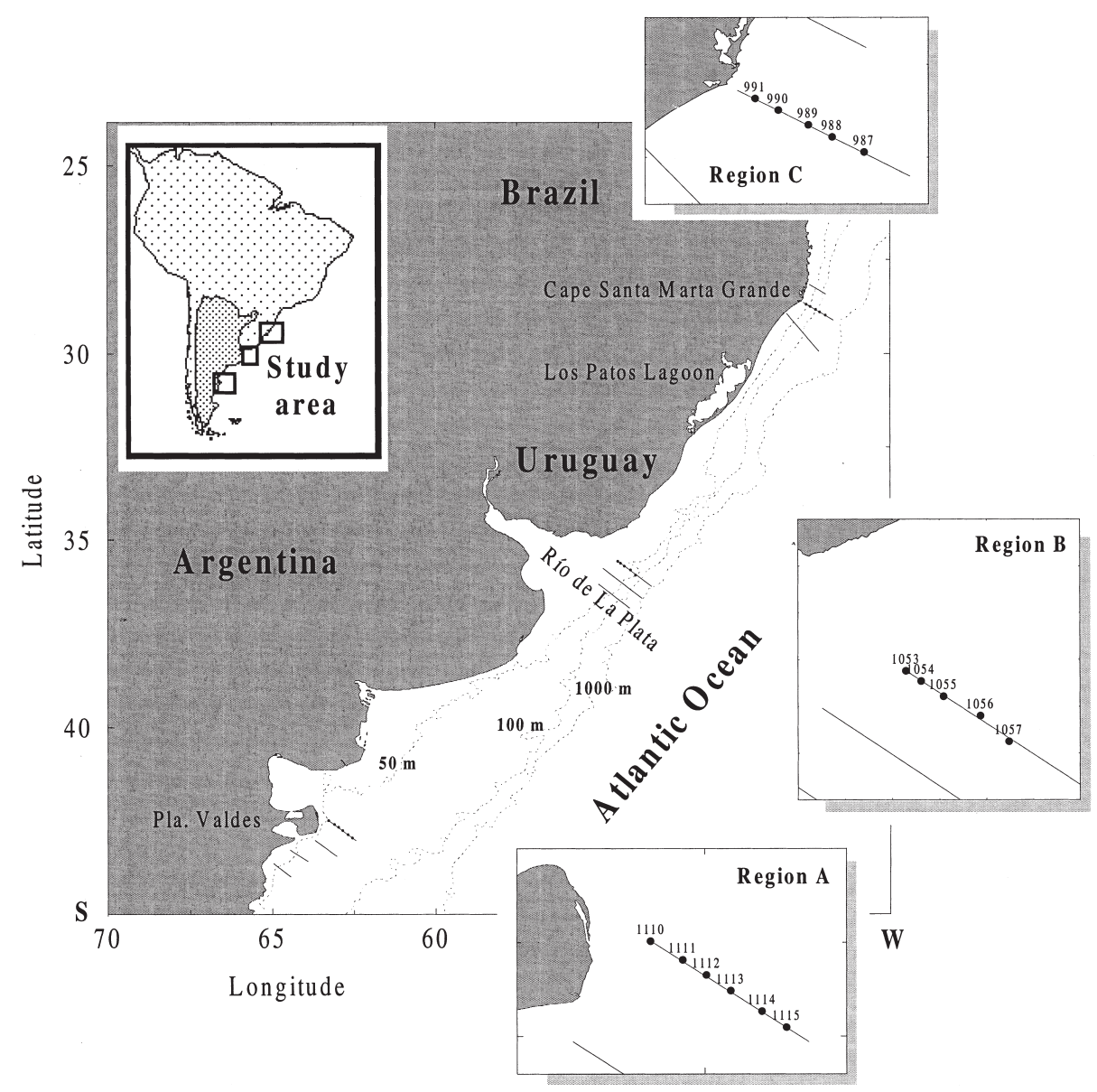

FIG. 1. - Sampling sections and station location of the survey carried out in three hydrographic systems (Region A: Argentina; Region B: Río de la Plata and Region C: Brazil), in the South-western Atlantic Ocean, with the R/V Meteor 11/3 in November-December 1989.

and the mixing of the coastal water is forced by vertical shear induced by tidal currents at particular topographic shoals south-east and north-east of the peninsula (Carreto et al., 1986a; Glorioso, 1987). Carreto et al. (1986a) demonstrated that this front is highly productive during the spring and summer.

Region B: The Río de la Plata is a coastal plain estuary, draining fresh/brackish water over the continental shelf through a $230 \mathrm{~km}$ width open mouth (Punta Rasa, Argentina to Punta del Este, Uruguay). Stratification is consequently controlled by the confluence of a high buoyancy continental discharge advecting offshore, lying on denser shelf water that intrudes into the estuary as a topographically-controlled wedge (Guerrero et al., 1997a). The external limit of the surface salinity front, where horizontal salinity gradients indicate the mixing limit between both systems, is observed in the study area (Guerrero et al., 1997b). Associated with this front, and limited to the upper few meters, a high chlorophyll$a$ concentration has been reported by the Servicio de Hidrografía Naval (1968), Hubold (1980) and Car- reto et al. (1986b). A high-productivity band along the front is maintained by injection of river nutrients and particulate matter from estuarine waters (re-supplied by bottom-up fluxes of shelf water), which is advected as a surface plume over the shelf regime.

Region C: Shelf water off Cape Santa Marta Grande is evenly stratified, with warm saline water at the surface driven by the SW Brazil Current overlying much cooler, fresher, and nutrient-rich subtropical water. The bottom is rather steep and narrow, as the shelf is just slightly over $100 \mathrm{~km}$ wide. The summer season is characterised by moderate dominant NE winds that force an upwelling condition at the coast (Matsuura, 1986). Less frequently, a downwelling condition is observed when winds reverse to a SW direction. Under either condition (up- or downwelling), a subsurface chlorophyll- $a$ maximum layer is present at coastal and near-coastal stations. This layer is maintained primarily by bottom-driven turbulence that injects South Atlantic Central Waters, rich in nitrate, to the euphotic zone (Odebrecht and Djurfeldt, 1996). 


\section{MATERIALS AND METHODS}

The field sampling was carried out on board the German R/V "Meteor" during November-December 1989 (Cruise 11/3). Macroplankton and micronekton were collected using a rectangular midwater trawl (RMT) (2 x 4m, 1mm-mesh size in the cod end) in the three areas from Brazilian, Uruguayan and Argentine Atlantic waters. A total of 70 hauls were made with this gear: 17 in the Argentine Region A, 12 in the Río de la Plata Region B and 41 in the Brazilian Region C (Figure 1). The samples were taken in sections of about 5 stations each. Information about cruise design, station work and hydrographic conditions are given in Nellen (1990) and Alheit et al. (1991). The average filtered volume was $9114.9 \mathrm{~m}^{3}$ (range 2765,7-20989 $\mathrm{m}^{3}$ ). Many sections were not completed because of bad weather conditions or excessive quantities of jelly plankton. In consequence, only one section in Regions A (Stations 1110-15) and B (Stations 1053-57) and 3 sections (15 stations: 982-996) in Region C were completed, the last being analysed as an average of the three sections. Identification was done "in situ", sorting, counting and weighting the large-sized material $(>1 \mathrm{~cm})$. Small-sized material $(<1 \mathrm{~cm})$ was fixed in formalin or alcohol for different purposes and was later analysed in the laboratory. Unidentifiable and damaged specimens were also stored in 4$8 \%$ formalin seawater solution for further identification in the laboratory.

For biomass analysis we followed the three categories used by Larson (1986a): gelatinous (Hydromedusae, Scyphomedusae, Siphonophora, Ctenophora and Salps); semigelatinous (Tomopteridae, Pteropoda, Heteropoda and Chaetognatha) and nongelatinous (Euphausiida, Stomatopoda, Caprellida, other Decapoda, Cephalopoda and Pisces). Standing stock was estimated by converting wet weight (ww) into org. $\mathrm{C}$ using the converting factors of Omori (1969), Baker (1973), Larson (1986a,b) and Schneider (1989). The results are expressed as mg org. C per $100 \mathrm{~m}^{3}$, to make them comparable with previous estimates of medusa biomass (Hay et al., 1990). Identification of gelatinous taxa is based on Mayer (1912), Kramp (1961), Alvariño (1981), Alvariño et al. (1990), Esnal (1981), Larson (1986b), Harbison (1986), Mianzan (1986a,b; 1989a; 1999) and Mianzan et al. (1988).

Temperature and salinity data were collected with a Mark III and a Smart Neil Brown CTDs (the last instrument used in the Brazil Region only) lead- ing to a final vertical resolution of $1 \mathrm{~m}$. A total of 239 vertical profiles were obtained: 45, 107 and 67 profiles in Regions A, B and C respectively (Alheit at al. 1991). The CTDs performed at each mid-water trawl (RMT) station were arranged along sections and were correlated with the associated biomass distribution. Temperature was used for describing the coastal front systems (off Brazil and Argentina) as this parameter determines the density stratification (Matsuura, 1986; Glorioso, 1987). Salinity was the parameter used for the estuarine system, as it controls density distribution (Guerrero, et al. 1997a).

\section{RESULTS}

In general, dominance by gelatinous macrozooplankton, compared with the other fraction of macrozooplankton and micronekton, was observed. Although specific composition was different for the three regions, mean standing stock of the gelatinous organisms was always greater than $50 \%$ of org. C along every section analysed.

The lobate ctenophora Mnemiopsis leidyi A. Agassiz, 1865, dominated the zooplankton biomass in the tidal front off Península Valdés (Region A,

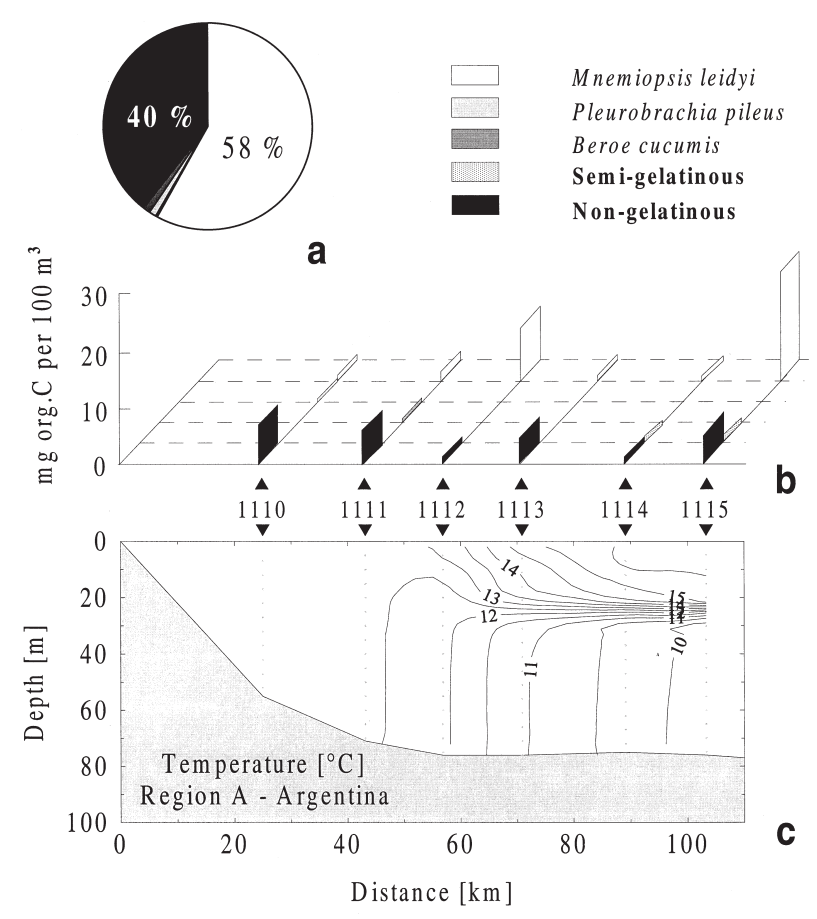

FIG. 2. - a: $\%$ of biomass contribution (mg org. C per $100 \mathrm{~m}^{3}$ ) of major components of the macrozooplankton; $b$ : distribution of major components of the macrozooplankton (mg org. C per $100 \mathrm{~m}^{3}$ ) and $\mathrm{c}$ : temperature vertical section along the northern section of Region A, off Argentina, during December 1989. 

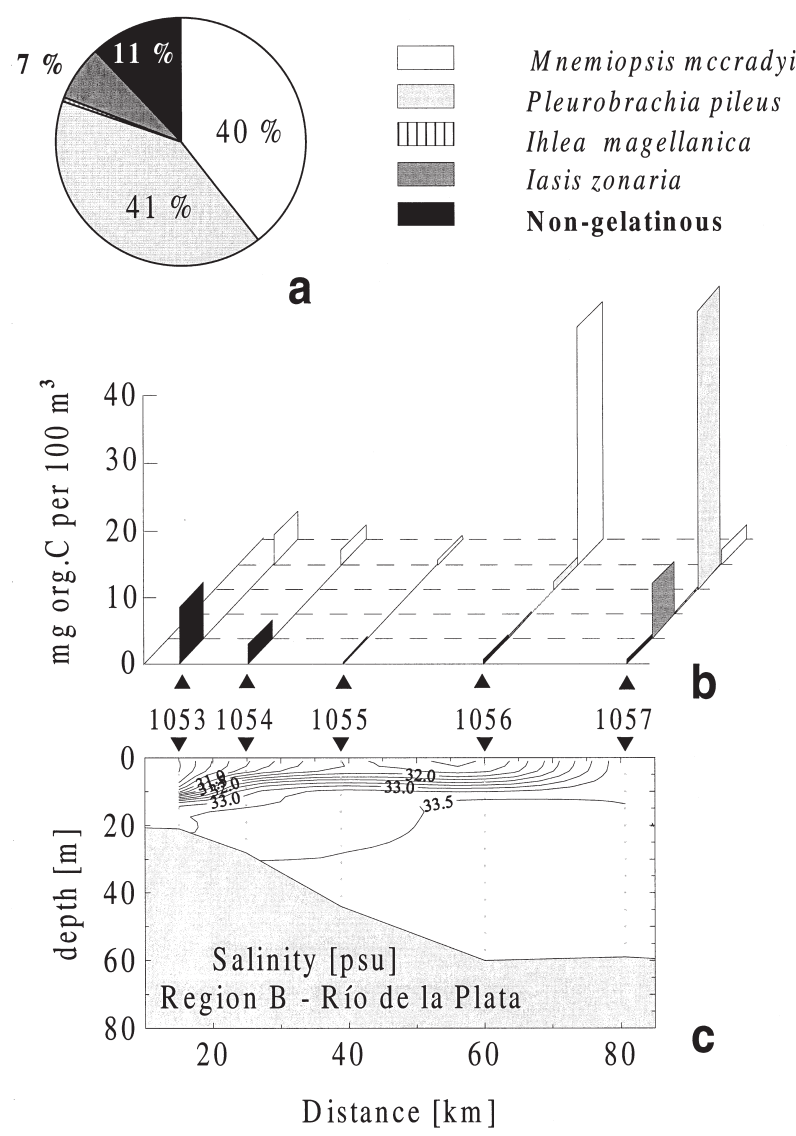

FIG. 3. - a: $\%$ of biomass contribution (mg org. C per $100 \mathrm{~m}^{3}$ ) of the major components of the macrozooplankton; b: distribution of major components of macrozooplankton (mg org. C per $100 \mathrm{~m}^{3}$ ) and c: salinity vertical section along the northern section of Region B, off Río de la Plata (Argentina-Uruguay), during November 1989.

Argentina). It represented almost $60 \%$ of total org. $\mathrm{C}$, and reached $20.2 \mathrm{mg}$ org. $\mathrm{C}$ per $100 \mathrm{~m}^{3}$ (Fig. 2a). It was more abundant in the deeper sampling stations of the section (Fig. 2b). The maximum value was observed at the highly stratified station (St.1115), and a secondary maximum was located at Station 1112, where the isotherm outcrops to the surface (Fig. 2c). Vertical temperature gradients at the stratified side were $0.5^{\circ} \mathrm{C} / \mathrm{m}\left(15\right.$ to $\left.10^{\circ} \mathrm{C}\right)$. Horizontal gradients were not strong $\left(0.6^{\circ} \mathrm{C} / 10 \mathrm{~km}\right)$. Small biomasses of the ctenophores Pleurobrachia pileus (O.F. Müller, 1776) and Beroe cucumis Fabricius, 1780, were also obtained here.

Non-gelatinous zooplankton was nearly evenly distributed across this section, represented by the crustacean Pterosquilla sp., euphausids, pycnogonids, tomopterids, the cephalopods Rossia tenera (Verril, 1880) and Illex sp. and fish larvae of Engraulis anchoita Hubbs and Marini,1935, Merluccius hubssi Marini, 1933 and Genypterus blacodes (Schneider, 1801).
Ctenophores were also dominant in the surface salinity front (Region B, Río de la Plata) in the northern section. The lobate Mnemiopsis mccradyi Mayer, 1900 and the cydippid Pleurobrachia pileus comprised $40 \%$ and $41 \%$ of total org. C (Fig. 3a) and reached maximum values of 35.25 and $42.9 \mathrm{mg}$ org. C per $100 \mathrm{~m}^{3}$ respectively. The presence of maximum concentrations of Mnemiopsis mccradyi was related to those stations located at the surface outcropping of the halocline (in the surface salinity front: St. 1053 and 1056), while Pleurobrachia pileus and the salp Iasis zonaria (Pallas, 1774) were dominant at the station 1057 that defines the outer limit of this outcropping (Figs. 3b, 3c). Another gelatinous member rarely collected, the salp Ilhea magellanica (Apstein, 1894), was also found here.

Horizontal salinity gradients of $0.1 \mathrm{psu} / \mathrm{km}$ and vertical gradients greater than $0.5 \mathrm{psu} / \mathrm{m}$ indicate, as expected, that salinity distribution controlled total stratification, even though a strong vertical temperature gradient was present $\left(0.5^{\circ} \mathrm{C} / \mathrm{m}\right)$. Horizontal temperature gradients were $0.64^{\circ} \mathrm{C} / 10 \mathrm{~km}$ (Fig. 3c).

Non-gelatinous zooplankton dominated the inner estuarine regime, represented by crustaceans including stomatopods, caprellids, euphausiids, mysids and others, cephalopods and pisces Engraulis anchoita and other unidentified fish larvae.

Gelatinous zooplankton was also the main component of the macrozooplankton biomass in the upwelling at Cape Santa Marta Grande (Region C, Brazil). In this case, the hydromedusae Rhacostoma atlantica L. Agassiz, 1850 and Olindias sambaquiensis Müller, 1861, dominated the total biomass (68\% and $7 \%$ of total org. C respectively) and reached very high biomass values. These values are one order of magnitude higher than in the other Regions (averages values 335 and $39 \mathrm{mg}$ org. C per $100 \mathrm{~m}^{3}$; maximum values: 572 and $80 \mathrm{mg}$ org. C per $100 \mathrm{~m}^{3}$ respectively). These two species were aggregated at coastal stations, where the $22^{\circ}$ and $23^{\circ} \mathrm{C}$ isotherms intersect the surface (Figs. $4 \mathrm{~b}$ and $4 \mathrm{c})$. These stations also showed the coolest temperature and shallowest thermoclines of the section. Calycophoran siphonophores Sulculeolaria quadrivalius Blainville, 1834, S. monoica (Chun, 1888), Lensia subtilis (Chun, 1886), Lensia hardy Totton, 1941, Agalma elegans (Sars, 1846), Diphes bojani (Eschscholtz, 1829), D. dispar Chamisso and Eisenhardt, 1821, Diphyopsis mitra (Huxley, 1859), Chelophyes appendiculata (Eschscholtz, 1829), Muggiaea kochi (Will, 1844), Abylopsis eschscholtzi (Huxley, 1859), A. tetragona (Otto, 
1823), Bassia bassensis (Quoy and Gaimard, 1833), and Enneagonum hyalinum Quoy and Gaimard, 1827 and the salps Thalia democratica (Forskål, 1775), Salpa maxima Forskål, 1775 and S. fusiformis Cuvier 1804 were the most abundant quantitatively, but their total biomass only reached 4\%. The scyphomedusae Aurelia aurita (Linné,1758) and Pelagia noctiluca (Forskål, 1775) contributed a further $2 \%$ to the total org. C. Other organisms collected in very small quantities were the ctenophores Beroe ovata Chamiso and Eysenhardt, 1821, Cestum veneris Lesueur, 1813, Pleurobrachia pileus and Mnemiopsis mccradyi, and the floating athecate hydroid Velella velella (Linné, 1758). Among the semi-gelatinous species, chaetognaths and pteropods were found. In the non-gelatinous category, we found stomatopod and caprellids crustaceans, pisces E. anchoita larvae, and the cephalopod Argonauta sp.

Along each section a different degree of stratification was observed. The stronger horizontal changes in the parameters considered here, off Peninsula Valdés (Region A, Argentina) and at the Río de la Plata (Region B, Argentina-Uruguay), define the tidal and estuarine fronts respectively at the outcropping of the isolines (Figs. $2 c$ and $3 c$ ). The upwelling at Cape Santa Marta Grande (Region C, Brazil) exhibits a relatively weaker front at the coastal stations (Fig. 4c). The tidal front off Peninsula Valdés was the only system with a purely homogeneous water column. The maximum biomass of Mnemiopsis leidyi was observed in the deeper station with the maximum stratification and a second biomass maximum was located at a frontal station. At the Río de la Plata estuary, the front is situated between Stations 1056 and 1057, associated with the maximum aggregation of Mnemiopsis mccradyi and Pleurobrachia pileus. The Brazilian Region showed a regime going from total to partial stratification at the coast. For all three sections performed, those stations with a relative maximum in hydromedusan biomass were situated at minimum stratification stations (onshore), where the isotherms outcrop to the surface.

\section{DISCUSSION}

Ctenophores and hydromedusae were found to dominate the gelatinous as well as total macroplanktonic biomass within the three hydrographic systems analysed here.

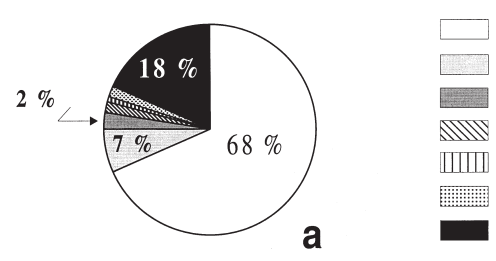

Rhacostoma atlantica Olindias sambaquiensis Scyphomedusae Siphonophora Thaliacea Semi-gelatinous Non-gelatinous

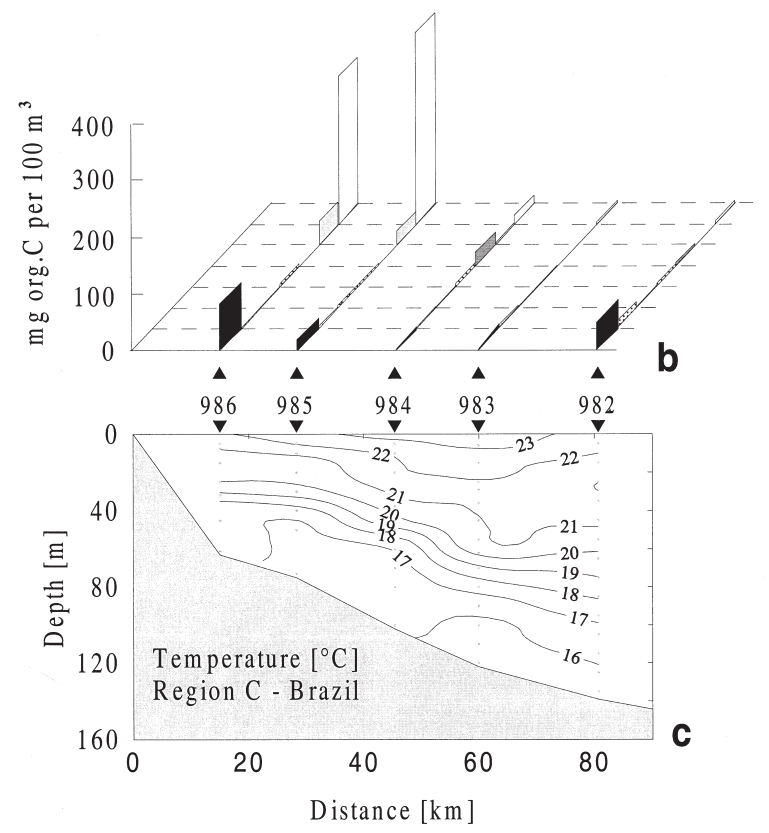

FIG. 4. - a: \% of biomass contribution (mg org. C per $100 \mathrm{~m}^{3}$ ) of major components of the macrozooplankton; b: distribution of major components of the macrozooplankton (mg org. C per $100 \mathrm{~m}^{3}$ ) and c: vertical temperature section along the central section of Region C, off Brazil, during November 1989.

Most previous papers stating that certain species of the gelatinous community reach important biomass are referring to scyphomedusae, usually having high individual weights. Shenker (1984) found that swarms of Chrysaora fuscescens Brandt, 1835 off the coast of Oregon contained at least $80 \%$ as much carbon as the densest concentration of copepods there. In the fall, Aurelia aurita has been found to reach a wet weight 20 times greater than that of the entire remaining plankton in the Black Sea (prior to the arrival of Mnemiopsis there) (Shushkina and Musayeva, 1983). However, biomass estimations of hydromedusae and moreover of Ctenophora are less abundant, and reference to their biomass contribution is sometimes underestimated.

In the tidal front off Península Valdés (Region A, Argentina), the ctenophore Mnemiopsis leidyi dominated the total biomass, although the values are small in comparison with others reported from the same location and cruise. As previously reported by Alheit et al. (1991) using a BIOMOC sampler, this species reached 20 times greater biomass (expressed 
as volume) in the stratified zone of a southern section. The RMT sampler was not used in areas with great concentrations of ctenophores due to its possible loss, so only the northern section (Stations 111015) was completed. There, the population of this ctenophore was in a juvenile stage (individuals of about $1 \mathrm{~cm}$ length) and we can assume that we sampled during the initial steps of development of the population. In consequence, a much higher gelatinous biomass should be expected within a short time. In the Azov Sea (Volovik et al., 1993) similar values for Mnemiopsis during the beginning of a bloom were reported $\left(10.5 \mathrm{mg} \mathrm{C}\right.$ org. per $\left.100 \mathrm{~m}^{3}\right)$.

In the river plume front of the Río de la Plata (Region B), gelatinous plankton also dominated the biomass and the ctenophore Mnemiopsis mccradyi was responsible for the aggregations observed. In the Río de la Plata area, aggregations of jelly plankton were also reported to dominate gelatinous and total biomass in Samborombón Bay $\left(36^{\circ} \mathrm{S}, 57^{\circ} \mathrm{W}\right)$. This ctenophore and the hydromedusa Liriope tetraphylla (Chamisso and Eysenhardt, 1821) peaked during spring and summer respectively, and represented $32 \%$ and $11 \%$ of the total biomass (15 and 4 $\mathrm{mg}$ org. $\mathrm{C} \mathrm{m}^{-3}$ ) (Sorarrain, 1998). This hydromedusa was not collected in significative numbers in the present study, probably because of its small number during this season and also due to the gear employed. Pleurobrachia pileus, another important component of the studied community, is more oceanic. It was found in association with several salps, usually in the Malvinas Current. A related species Pleurobrachia bachei, also reaching important biomass ranked first in Saanich Inlet, British Columbia (Larson, 1986c).

Off Cape Santa Marta Grande (Region C, Brazil) two hydromedusae were significantly abundant. Rhacostoma atlantica is a common neritic and mesopelagic species, well documented for the South-western Atlantic Ocean (Bouillon, 1999). Olindias sambaquiensis, also a neritic species, affects summer recreational activities on the Argentine coast (Mianzan, 1989b; Mianzan and Ramírez, 1996). High concentrations of both of these species have not been reported previously for these waters, even though it has been established that off shore winds increase the probability of finding Olindias on the beaches, giving upwelling condition (Mianzan and Zamponi, 1988).

According to Arai (1992), aggregations of hydromedusae are due to a combination of the effects of physical forces and behavioural responses, being often difficult to distinguish between passive and active factors. A passive factor contributing to gelatinous aggregation in Regions A (tidal front) and B (Río de la Plata estuary) is the vertical stratification of the water column. In Region C (Cape Santa Marta Grande), aggregation observed in the less-stratified sector seems to be controlled by the upwelling of deeper offshore waters driven by NE winds. A common feature found in all three systems was the presence of isolines emerging to the surface. This outcropping indicates a break of the stratification and the formation of a front that separates a stratified regime from a homogeneous one. These fronts are associated with the convergence of waters and accumulation of particulate matter and planktonic organisms (see Bowman and Esaias, 1977). Intensification of mixing between both regimes also characterizes the frontal area, as does a vertical enhancement of nutrient flux and increasing of primary productivity (Pingree et al., 1978; Kiørboe, 1993; Odebrecht and Djurfeldt, 1996).

There is a general lack of information on trophic processes in the study area. However, in terms of some active factors, available literature on spatial distribution of phyto-, micro- and mesozooplankton permits us to infer that feeding requirement of gelatinous plankton could be fulfilled in each of the three hydrographic systems under study.

The tidal front is the main feature analysed in Region A, Argentina. The stratified zone of the front is dominated by the dinoflagellate Alexandrium tamarense (= Gonyaulax excavata (Braarud)), whereas the homogeneous sector was dominated by chain-forming diatoms (Carreto et.al, 1986a). The horizontal distribution of microzooplankton (mainly copepods eggs and nauplii) showed the highest values of abundance at the transitional zone, in coincidence with the maximum values of chlorophyll- $a$ (Viñas and Ramírez, 1996). Mesozooplankton (e.g. copepods, mainly calanoids) has its maximum values in the stratified zone (Möhlenkamp, 1996). Mnemiopsis leidyi was found in the stratified zone of the front, in agreement with the hypothesis of Greve and Parsons (1977).

The Río de la Plata surface salinity front (Region B) showed a maximum of chlorophyll- $a$ (Carreto $e t$ al., 1986b). According to Gayoso (1996), dinoflagellates and coccolitophores dominated the phytoplankton assemblages in the outer area. Information on micro- and mesozooplankton of the area is scarce. Sorarrain (1998) found that Mnemiopsis mccradyi peaked in concordance with the increase 
of Acartia tonsa, the dominant copepod species within Samborombón Bay. Mnemiopsis spp. elsewhere also show a strong association with warm temperatures and waters dominated by the copepod Acartia tonsa, a fast-growing, ubiquitous, smallsized species typical of warm coastal environments (Kremer, 1994). Ctenophores are known to swarm in localised patches elsewhere, and it has been postulated that they may be dependent on dense aggregations of prey to support high metabolic demands (Larson, 1987). Mianzan and Sabatini (1985) established that the Mnemiopsis peaks observed at Blanca Bay $\left(39^{\circ} \mathrm{S}, 61^{\circ} \mathrm{W}\right)$ were related to food availability. Modelling studies seem to support this statement, having shown that food availability is the key factor in determining maximum ctenophore biomass (Kremer, 1994). A trophic pathway ending in gelatinous plankton corresponds to patterns proposed by Greve and Parsons (1977).

In Region C (Brazil), analysis of material from the same cruise as studied here states that primary production is very high at the on-shore stations, during both, upwelling and downwelling conditions. This production is sustained by large diatom chains generating the most important phytoplankton biomass along the section (Odebrecht and Djurfeldt, 1996). Matsuura and Kitahara (1995) stated that eggs and small larvae of the anchovy Engraulis anchoita were found predominantly in warm, nearshore waters above the thermocline. The species of hydromedusae that dominated the biomass in this area, Rhacostoma atlantica and Olindias sambaquiensis, are active predators. Olindias in particular is capable of consuming fishes as big as its bell diameter (Zamponi and Mianzan, 1985) and a species related to Rhacostoma, Aequorea sp., includes eggs and fish larvae in its diet (see Alvariño, 1985; Purcell, 1989). During upwelling conditions, it is probably not by chance that these two species are advected to the coast by wind-induced currents (Mianzan and Zamponi, 1988), as their shapes resemble a parachute that undoubtedly contributes to such movement. It is also possible that they were neglected in previous works because the gear employed to collect plankton (Bongo net, Nackthai, multinet, etc) is often inappropriate for sampling very large hydromedusae.

Higher jellyfish biomasses were found in the tidal front off Península Valdés and the Río de la Plata outflow, as well as in the upwelling of Cape Santa Marta Grande, so when one compares different kinds of systems (convergent and divergent areas), this results seems to be collectively coincident with Mills (1995). However, when one considers each of the systems separately, the trophic pathways proposed by Greve and Parsons (1977) seem to be observed in each of them. The spatial distribution of gelatinous plankton biomass analysed along sections for the three areas was not homogeneous, as jellyfishes and ctenophores tended to aggregate in particular areas of each hydrographic feature. These areas of aggregation corresponded mainly to the presence of isolines outcropping to the surface, where higher production processes occurred, satisfying metabolic requirements of the aggregation of gelatinous populations maintained there.

As a general conclusion, it is suggested that local environmental patterns exert control on the distribution of biomass of gelatinous predators. Consequently it is suggested that further work on vertical distribution and succession patterns, as well as better spatial coverage of the sections of the different regimes, is needed in order to properly asses those hydrographic features.

\section{ACKNOWLEDGEMENTS}

The German Research Association (DFG) and the German Ministry for Research and Technology (BMFT) supported the research vessel. We would like to thank Prof. W. Nellen and Dr. J. Alheit for providing travelling and shipboard facilities through the IOC-SARP programme. This paper was partially supported by a grant from UNESCO/ORCYT (870.614.1(V), NOV-1991) and SECyT (1990). We also want to acknowledge the kind reception at the Zooplankton Lab (Dr. M. Montú, FURG, Brazil) and INAPE (Dr. E. Goberna, Uruguay) in order to analyse the samples deposited there. Drs. T. Parsons (Canada), C. Bremec (Argentina) and R. Elías (Argentina) generously commented and made valuable suggestions about the manuscript. Dr. Y. Matsuura (Brazil) and Dr. L. Djurfeldt (Sweden) kindly sent us the oceanographic data set from Meteor Cruise 11/3. Dr. Phil Pugh (Southampton, UK) and Lic L. Machinandiarena (INIDEP, Argentina), kindly identified the Siphonophores and Salps and fish larvae, respectively. Lic. O. Pin (INAPE, Uruguay), MSc. I. D'apremont Lima (FURG. Brazil) and Dr. W. Ekau (ZTE, Germany), were responsible for the RMT samples on board and generously provided us with information on the sampled areas. The help from the scientists and crew of the R/V "Meteor" is deeply appreciated. 


\section{REFERENCES}

Alheit, J., J. Ciechomski, L. Djurfeldt, C. Ebel, M. Ehrlich, J. Elgue, G. Mantero, Y. Matsuura, H. Mianzan, W. Nellen, C. Oderbretch, F. Ramírez, R. Sanchez, G. Shaffer and M. Viñas. 1991. SARP studies on Southwest Atlantic anchovy, Engraulis anchoita off Argentina, Uruguay and Brazil. ICES., France, 46 (V): 1-32.

Alvariño, A. - 1981. Siphonophorae. In D. Boltovskoy ed. Atlas Del Zooplancton Del Atlantico Sudoccidental, Publ. Esp. Inidep: 383-441.

Alvariño, A. - 1985. Predation in the plankton realm; mainly with reference to fish larvae. Inv. Mar. Cicimar, 2(1): 1-122.

Alvariño, A., M. Wojtan M. and M. Martinez. - 1990. Antarctic Siphonophores from Plankton samples of the United States Antarctic Research Program: Eltain Cruises for Spring, Summer, Fall and Winter. Biol. Antarctic Sea XX, Antarctic Res. Ser. 49: 1-436.

Arai, M.N. - 1988. Interactions of fish and pelagic coelenterates. Can. J. Zool., 9: 1913-1927.

Arai, M.N. - 1992. Active and passive factors affecting aggregations of Hydromedusae: a review. In: Aspects of Hydrozoan Biology J. Bouillon, F. Boero, F. Cicogna, J.M.Gili and R. Hughes (Eds.). Sci. Mar., 56(2-3): 99-108.

Baker, L. D. - 1973. The ecology of the ctenophore Mnemiopsis mccradyi in Biscayne Bay, Florida. M. Sc. Thesis, University of Miami, Rosentiel School of Marine Science, $131 \mathrm{pp}$

Bakun, A. and R.H. Parrish. - 1991. Comparative studies of coastal pelagic fish reproductive habitats: the anchovy (Engraulis anchoita) of the southwestern Atlantic. Ices J. Mar. Sci., 48: 343-361.

Bernard, P. - 1984. Note sur l'invasion de la meduse Pelagia noctiluca sur la Riviera Francaise durant l'ete 1982. Proc. Workshop on Jellyfish Blooms in the Mediterranean, Unep, Athenas, Grecia: $128-132$

Boero, F. - 1991. Contribution to the understanding of blooms in the marine environment. In: UNEP: Jellyfish blooms in the Mediterranean. Proc. II Workshop on Jellyfish in the Mediterranean Sea. Map Tech. Rep. Ser. 47: 72-76.

Bouillon, J. - 1999. Hydromedusae. In: D. Boltovskoy (ed.), South Atlantic Zooplankton pp. 385-465. Backhuys Publishers, Leiden.

Bowman, M.J. and W.E. Esaías, (eds.). - 1977. Oceanic fronts in coastal processes. Springer-Verlag, Berlin, Heidelberg, New York. $114 \mathrm{pp}$.

Carreto, J.I., H.R. Benavides, R.M. Negri and P.D. Glorioso. 1986a. Toxic red-tide in the Argentine Sea. Phytoplankton distribution and survival of the toxic dinoflagellate Gonyaulax excavata in a frontal area. J. Plankton Res., 8(1): 15-28.

Carreto, J., R.M. Negri and H. Benavides. - 1986b. Algunas características del florecimiento del fitoplancton en el frente del Río de La Plata. Parte I: Los sistemas nutritivos. Rev. Invest. Des. Pesq., 6: 7-29.

Elgue, J., C. Baysse, M. Parietti and F. Burone. - 1986. Campaña de invierno 1983. I. Oceanografía física. Publ. Com. Tec. Mix. Fr. Mar., 1: 204-217.

Emilsson, I. - 1961. The shelf and coastal waters off southern Brazil. Bol. Inst. Oceanogr., S. Paulo, 11 (2): 101-112.

Esnal, G.B. - 1981. Thaliacea: Salpidae. In: D. Boltovskoy (ed.), Atlas del Zooplancton del Atlántico Sudoccidental, pp. $793-$ 808. Publ. Esp. Inidep.

Gayoso, A.M. - 1996. Phytoplankton species composition and abundance off Río de la Plata (Uruguay). Arch. Fish. Mar. Res. 44 (3): 257 - 265.

GESAMP (Joint Group of Experts on the Scientific Aspects of Marine Environmental Protection). - 1997. Opportunistic settlers and the problem of the ctenophore Mnemiopsis leidyi invasion in the Black Sea. Rep. Stud. GESAMP, 58: 84 pp.

Glorioso, P. - 1987. Temperature distribution related to shelf-sea fronts on the Patagonian shelf. Cont. Shelf Res., 7: 27-34

Greve, W. and T. R. Parsons. - 1977. Photosynthesis and fish production: Hypothetical effects of climate changes and pollution. Helgoländer wiss. Meeresunters, 30: 666-672.

Guerrero, R.A., M.E. Acha, M.E. Framiñan and C. Lasta. - 1997a. Physical Oceanography of the Río de la Plata Estuary. Cont. Shelf Res., 17 (7): 727-742.

Guerrero, R.A, C. Lasta, M.E. Acha, H. Mianzan and M.E.
Framiñan. - 1997b. Atlas Hidrográfico del Río de la Plata. Comisión Administradora del Río de la Plata - Instituto Nacional de Investigación y Desarrollo Pesquero. Buenos Aires - Montevideo. $109 \mathrm{pp}$.

Hay, S. J.R. Hislop and A.M. Shanks. - 1990. North Sea Scyphomedusae; summer distribution, estimated biomass and significance particularly for 0-Groups gadoid fish. Netherlands J. Sea Res., 25(1/2): 113-130.

Harbison, G.R. - 1986. Toward a study of the Biogeography of pelagic coelenterates. In: A.C. Pierrot-Bults, S. Van Der Spoel, B.J. Zahuranec and R.K. Johnson (eds.), Pelagic Biogeography., Unesco Press, Unesco Tech. Pap. Mar. Sci., 49: 112- 117.

Hubold, G. - 1980. Hydrography and plankton off Southern Brazil and Río de la Plata, August - November 1977. Atlantis 4: 1-22.

Kiørboe, T. - 1993. Turbulence, phytoplankton cell size, and structure of pelagic food webs. Advan. Mar. Biol., 29: 1-72.

Kramp, P.L. - 1961. Synopsis of the medusae of the world. J. Mar. Biol. Ass. Uk, 40: 7-469.

Kremer, P. - 1994. Patterns of abundance for Mnemiopsis in US coastal waters: A comparative overview. ICES J. Mar. Sci., 51: 347-354.

Larson, R.J. - 1986a. Pelagic Scyphomedusae (Scyphozoa: Coronatae and Semaeostomae) of the Southern Ocean. Biol. Antarctic Seas XIV, Antarctic Res. Ser., 41(3): 59-165.

Larson, R.J. - 1986b. Water content, organic content and carbon and nitrogen composition of medusae from the north-east Pacific. J. Exp. Mar. Biol. Ecol., 99: 107-120.

Larson, R.J. - 1986c. Seasonal changes in the standing stocks, growth rates and production rates of gelatinous predators in Saanich Inlet, British Columbia. Mar. Ecol. Prog. Ser., 33: 89-98.

Larson, R.J. - 1987. In situ feeding rates of the ctenophore Mnemiopsis mccradyi. Estuaries, 10: 87-91.

Legovic, T. - 1991. Causes, consequenses and possible control of massive occurrence of jellyfish Pelagia noctiluca in the Adriatic Sea. In: UNEP: Jellyfish blooms in the Mediterranean. Proc. II Workshop on Jellyfish in the Mediterranean Sea. Map Tech. Rep. Ser., 47: 128-132.

Longhurst, A., S. Sathyendranath, T. Platt and C. Caverhill. - 1995. An estimate of global primary production in the ocean from satellite radiometer data. J. Plankton Res. 17(6): 1245-1271.

Matsuura, Y. - 1986. Contribuçao ao estudio sobre estrutura oceanografica da regiao sudeste entre Cabo Frío (RJ) e Cabo de Santa Marta Grande (SC). Ciencia E Cultura, 38(8): 14391450.

Matsuura, Y. and E.M. Kitahara - 1995. Horizontal and vertical distribution of anchovy Engraulis anchoita eggs and larvae off Cape Santa Marta Grande in southern Brazil. Arch. Fish. Mar. Res., 42(3): 239-250.

Mayer, A.G. - 1912. Ctenophores of the Atlantic Coast of North America. Carnegie Inst. Washington Publ., 162: 1-58.

Mianzan, H.W. - 1986a. Estudio sistemático y bioecológico de algunas medusas Scyphozoa de la región subantártica. Tesis Doctoral, Fac. Cs. Naturales Y Museo, Univ. Nac. La Plata, 196 pp.

Mianzan, H. - 1986b. Beroe ovata en aguas de la bahía Blanca, Argentina (Ctenophora). Spheniscus, 2: 29-32.

Mianzan, H.W. - 1989a. Sistemática y zoogeografía de scyphomedusae en aguas neríticas argentinas. Rev. Inv. Mar. Cicimar, 4(1): $15-34$

Mianzan, H.W. - 1989b. Distribución de Olindias sambaquiesis Müller, 1861 (Hydrozoa, Limnomedusae) en el Atlántico Sudoccidental. Iheringia, Ser. Zool., 69: 155-157.

Mianzan, H. - 1999. Ctenophora. In: D. Boltovskoy (ed.), South Atlantic Zooplankton pp. 561-573. Backhuys Publishers, Leiden.

Mianzan, H. and P.F.S. Cornelius. - 1999. Cubomedusae and Scyphomedusae. n: D. Boltovskoy (ed.), South Atlantic Zooplankton pp. 513-559. Backhuys Publishers, Leiden.

Mianzan, H., G. Olagüe and R. Montero. - 1988. Scyphomedusae de las aguas Uruguayas. Spheniscus, 6: 1-9.

Mianzan, H. and F. Ramírez. - 1996. Olindias sambaquiensis stings in the South west Atlantic. In: Williamson JAH, Fenner PJ, Burnett JW and JF Rifkin (Eds.), Venomous and Poisonous Marine Animals: a medical and biological handbook pp. 206208 and 301. Univ. New South Wales Press., Brisbane, Australia.

Mianzan, H.W. and M.E. Sabatini. - 1985. Estudio preliminar sobre distribución y abundancia de Mnemiopsis maccradyi en el estuario de Bahía Blanca (Ctenophora). Spheniscus, 1: 53- 68. 
Mianzan, H.W. and M. Zamponi. - 1988. Estudio bioecológico de Olindias sambaquiensis Muller, 1861 (Limnomedusae, Olindiidae) en el área de Monte Hermoso. II. Factores meteorológicos que influyen en su aparición. Iheringia ,Ser. Misc., (02): 63-68.

Miller, G.R. - 1966. The flux of tidal energy out of the deep oceans. J. Geophys. Res., 71: 2485-2489.

Mills, C.E. - 1995. Medusae, siphonophores and ctenophores as planktivorous predators in changing global ecosystems. Ices $J$. Mar. Sci., 52: 575-581.

Möhlenkamp, M. - 1996. Untersuchungen zur kleinskaligen Verteilung von Mikro- und Mesozooplankton im oberen Pelagial des südamerikanischen Schelfmeeres unter Erprobung eines neuen automatischen Messgeråtes. Dissertation zur Erlangung des Doktorgrades am Fachbereich Biologie der Universităt Hamburg, $112 \mathrm{pp}$.

Möller, H. - 1978. Significance of coelenterates in relation to other plankton organisms. Meeresforschung, 27(1): 703-712.

Möller, H. - 1980. A summer survey of large zooplankton, particularly scyphomedusae, in North Sea and Baltic. Meeresforschung, 28: 61-68.

Möller, H. - 1984. Some speculations on possibilities of controlling jellyfish blooms. Proc. Workshop on Jellyfish Blooms in the Mediterranean, Unep, Athenas, Grecia: 211-215.

Nellen, W. - 1990. Working report on Cruise $\mathrm{N}^{\circ} 11$, Leg 3 of RV METEOR. Inst. Hydrobiol. Fischereissenschaft, 9: 158 p.

Odebrecht, C. and L. Djurfeldt - 1996. The role of nearshore mixing on phytoplankton size structure off Cape Santa Marta Grande, southern Brazil (Spring 1989). Arch. Fish. Mar. Res., 43 (3): 217 - 230

Omori, M. - 1969. Weight and chemical composition of some important oceanic zooplankton in the North Pacific Ocean. Mar. Biol., 3: 4-10.

Papathanassiou, E., P. Panayotidis and K. Anagnostaki - 1987. Notes on the biology and ecology of the jellyfish Aurelia aurita L. in Elefis Bay (Saronikos Gulf, Greece). Mar. Ecol., 8: 49-58.

Parsons, T.R. - 1979. Some ecological, experimental and evolutionary aspects of the upwelling ecosystem. South African J. Sci., 75: 536-540.

Parsons, T.R. - 1993. The need for a holistic approach to ocean ecology. Limnol. Oceanogr., 38: 1590-1592.

Parsons, T. R. - 1996. Taking stock of fisheries management. Fisheries Oceanogr., 5(3/4): 224-226.

Pingree, R.D., P.M. Holligan and G.T. Mardell. - 1978. The effects of vertical stability on phytoplankton distributions in the summer on the northwest European shelf. Deep Sea Res., 25: 1011-1028.

Purcell, J.E. - 1989. Predation on fish larvae and eggs by the hydromedusa Aequorea victoria at a herring spawning ground in British Columbia. Can. J. Fish. Aquat. Sci., 46: 1415-1427.
Rottini Sandrini, L. and M. Avian. - 1991. Reproduction of Pelagia noctiluca in the central and Northern Adriatic Sea. Hydrobiologia, 216/217: 197-202

Rottini Sandrini, L. and F. Stravisi. - 1981. Preliminary report on the occurrence of Pelagia noctiluca (Semaeostomeae, Pelagiidae) in Northern Adriatic. Rapp. Comm. Mer. Medit., 27(7): 147-148.

Schneider, G. - 1989. Carbon and nitrogen content of marine zooplancton dry material, a short review. Plankton News., 11: 4-6.

Servicio de Hidrografía Naval. - 1968. Datos y resultados de las campañas Pesquerías II, III, IV y V. Proyecto de Desarrollo Pesquero, Series de Infs. téc. 10/II, 10/III, 10/IV y 10/V.

Shenker, J. - 1984. Scyphomedusae in surface waters near the Oregon coast, May-August. Estuar. Coast. Shelf Sci., 19: 619-632.

Shushkina, E. and E. Musayeva - 1983. The role of jellyfish in the energy system of Black Sea plankton communities. Oceanology, 22: 92-96.

Simpson, J. H. and D. Bowers - 1981. Models of stratification and frontal movement in shelf seas. Deep Sea Res., Vol. 28A (7): 727-738.

Smayda, T. J. - 1993. Experimental manipulations of phytoplankton + zooplancton + ctenophore communities and foodweb roles of the ctenophore, Mnemiopsis leidyi. ICES-CM-1993/ L: $68,13 \mathrm{pp}$.

Sorarrain, D. - 1998. Cambios estacionales en la biomasa de organismos gelatinosos en relación a otros zooplancteres en la bahía Samborombón. Fac. Cs. Exts. y Nats., UNMdP., 35 pp.

Vinogradov, M., E. Shushkina, E. Musayeva and P. Yu Sorokin. 1989. A new acclimated species in the Black Sea: the ctenophore Mnemiopsis leidyi (Ctenophora: Lobata). Oceanology, 29(2): 220-224.

Viñas, M. D. and F. C. Ramírez. - 1996. Gut analysis of first-feeding anchovy larvae from the Patagonian spawning areas in relation to food availability. Arch. Fish. Mar. Res. 43 (3): 231-256.

Volovik S., Z. Myrzoyan and G.S. Volovik. - 1993. Mnemiopsis leidyi in the Azov Sea: Population dinamics, impact to the ecosystem and fisheries. ICES Statut. Meeting, C.M. 1993/L:69: $11 \mathrm{p}$

Zaika, V.E. - 1972. The specific production of the aquatic invertebrates (Udelenayaproduccia vodnih bespozvonochnyih) Navkova Dumka, Kiev, 148 pp.

Zaika, V. and N. Sergeyeva. - 1990. Morphology and development of Mnemiopsis mccradyi (Ctenophora, Lobata) in the Black Sea. Hydrobiol. J., 26(1): 1-6.

Zamponi, M. and H. Mianzan. - 1985. La mecánica de captura y alimentación de Olindias sambaquiensis Muller, 1861 (Limnomedusae) en el medio natural y en condiciones experimentales. Historia Natural, Corrientes, 5(30): 269-278. 